\title{
Fe-Mg-O (Iron-Magnesium-Oxygen)
}

\section{Raghavan}

The early results on this ternary system were reviewed by [1989Rag], who presented four partial isothermal sections at 1800 and $1600{ }^{\circ} \mathrm{C}$ from [1962Phi], $1300{ }^{\circ} \mathrm{C}$ from [1967Spe] and $1000{ }^{\circ} \mathrm{C}$ from [1980Shi]. Recently, as part of their study of the Fe-Mg-Zn-O quaternary system, [2004Han] re-determined the solvus boundaries of the pseudo-binary section along the $\mathrm{Fe}_{2} \mathrm{O}_{3}-\mathrm{MgO}$ join.

\section{Binary Systems}

The Fe-Mg phase diagram [Massalski2] contains no intermediate phases and the mutual solid solubility between $\mathrm{Fe}$ and $\mathrm{Mg}$ is very limited. The $\mathrm{Fe}-\mathrm{O}$ phase diagram [1991Wri] exhibits the following compounds. Wustite (FeO) is a metal-deficient monoxide with the $B 1$, NaCl-type cubic structure. Magnetite $\left(\mathrm{Fe}_{3} \mathrm{O}_{4}\right)$ has the $\mathrm{Hl}_{1}, \mathrm{Al}_{2} \mathrm{MgO}_{4}$-type cubic structure. Hematite $\left(\mathrm{Fe}_{2} \mathrm{O}_{3}\right)$ is $D 5_{1}$-type rhombohedral. Other less-common polymorphic forms of the above compounds are known [1991Wri]. In the Mg-O system [Massalski2], periclase $(\mathrm{MgO})$ has the $B 1$, NaCl-type cubic structure. $\mathrm{MgO}_{2}$ has the pyrite-type cubic structure.

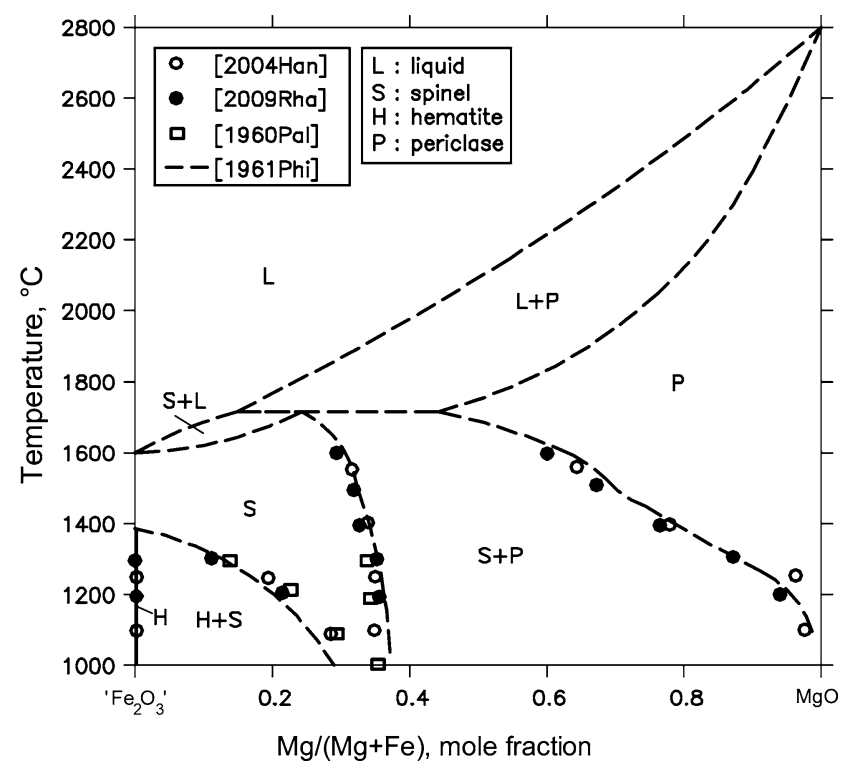

Fig. 1 Fe-Mg-O pseudo-binary section in air along the $\mathrm{Fe}_{2} \mathrm{O}_{3}$ $\mathrm{MgO}$ join

\section{The $\mathrm{Fe}_{2} \mathrm{O}_{3}-\mathrm{MgO}$ Pseudo-Binary Section}

With starting powders of $\mathrm{Fe}_{2} \mathrm{O}_{3}$ and $\mathrm{MgO}(99.5+\%$ purity), [2004Han] annealed pellets of powder mixtures in air between 1100 and $1550{ }^{\circ} \mathrm{C}$, followed by quenching. The phase compositions were measured by electron probe microanalysis and listed. More recently, [2009Rha] reported a limited number of experimental results on samples equilibrated between 1600 and $1200{ }^{\circ} \mathrm{C}$. Figure 1 shows this pseudo-binary section, incorporating the results of [1960Pal], [1961Phi], [2004Han] and [2009Rha]. $\mathrm{Fe}_{2} \mathrm{O}_{3}$ (hematite) dissolves very little $\mathrm{Mg}$. The Fe solubility in $(\mathrm{Fe}, \mathrm{Mg})_{3} \mathrm{O}_{4}$ (spinel) as well as in $\mathrm{MgO}$ (periclase) increases sharply with increasing temperature.

\section{References}

1960Pal: A.E. Paladino, Phase Equilibria of the Ferrite Region of the System FeO-MgO-Fe $\mathrm{O}_{3}$, J. Am. Ceram. Soc., 1960, 43(4), p 183-191

1961Phi: B. Phillips, S. Somiya, and A. Muan, Melting Relations of Magnesium Oxide-Iron Oxide Mixtures in Air, J. Am. Ceram. Soc., 1961, 44(4), p 167-169

1962Phi: B. Phillips and A. Muan, Phase Equilibria in the System $\mathrm{MgO}-\mathrm{FeO}-\mathrm{Fe}_{2} \mathrm{O}_{3}$ in the Temperature Range of 1400 to $1800^{\circ} \mathrm{C}$, J. Am. Ceram. Soc., 1962, 45(12), p 588-591

1967Spe: D.H. Speidel, Phase Equilibria in the System MgO$\mathrm{FeO}-\mathrm{Fe}_{2} \mathrm{O}_{3}$ : The $1300^{\circ} \mathrm{C}$ Isothermal Section and Extrapolations to Other Temperatures, J. Am. Ceram. Soc., 1967, 50(5), p 243248

1980Shi: V.I. Shishkov, A.A. Lykasov, and A.F. Il'ina, Activity of the Components of Iron-Magnesium Spinel, Zhur. Fiz. Khim., 1980, 54(3), p 766-767, in Russian; TR: Russ. J. Phys. Chem., 1980, 54(3), p 440-441

1989Rag: V. Raghavan, The Fe-Mg-O (Iron-Magnesium-Oxygen) System, Phase Diagrams of Ternary Iron Alloys. Part 5: Ternary Systems Containing Iron and Oxygen, Indian Institute of Metals, Calcutta, 1989, p 170-180

1991Wri: H.A. Wriedt, The Fe-O (Iron-Oxygen) System, J. Phase Equilib., 1991, 12(2), p 170-200

2004Han: R. Hansson, P.C. Hayes, and E. Jak, Phase Equilibria at Sub-Solidus Conditions in the Fe-Mg-Zn-O System in Air, Scand. J. Metall., 2004, 33, p 355-361

2009Rha: M.A. Rhamdhani, T. Hidayat , P.C. Hayes, and E. Jak, Subsolidus Phase Equilibria of Fe-Ni-X-O (X $=\mathrm{Mg}, \mathrm{Al})$ Systems in Air, Metall. Mater. Trans. B, 2009, 40B, p 25-38 